\title{
COVID-19 Pandemic; a call for a reality check
}

\author{
Ranil Fernando \\ Department of Surgery, Faculty of Medicine, University of Kelaniya, Ragama, Sri Lanka.
}

Correspondence: Professor Ranil Fernando

e-mail: ranilfern@sltnet.lk

https://orcid.org/0000-0003-4479-1716

\section{The backdrop}

A virus of the Beta coronavirus $2 \mathrm{~B}$ lineage was first discovered in December 2019, in three bronchoalveolar lavage samples of a Chinese patient who was affected by pneumonia of unknown aetiology (1), in a hospital in Wuhan the capital of the Hubei Province in China. The doctors treated the patient and not much was thought of the virus at that time. Doctors, Li Wenliang and Ai Fen realized the dangers of the new virus. They wrote about it in social media. They were reprimanded and warned sternly by the authorities in China. On $8^{\text {th }}$ January 2020, the Wuhan Public Security Bureau arrested eight doctors who had posted information about the illness on social media. An official at the Hubei Provincial Health Commission ordered laboratories, which had already determined that the novel virus was similar to SARS-CoV which caused severe acute respiratory syndrome in 2003; to stop testing samples and to destroy existing samples. On $13^{\text {th }}$ January, the first coronavirus patient was reported in Thailand, the first known case outside China. On $20^{\text {th }}$ January the first corona virus patient was reported in South Korea. A few days later patients were reported from Japan and USA. The warning signs of an epidemic were emerging but the Chinese authorities were still in a denial mode. Soon the Chinese authorities realized their mistake.

On $21^{\text {st }}$ of January, China's top political commission in charge of law and order warned that "anyone who deliberately delays and hides the reporting of [virus] cases out of his or her own self-interest will be nailed on the pillar of shame for eternity" (2).

On $23^{\text {rd }}$ January, Wuhan and three other cities are put on lockdown. As China celebrated the Lunar New Year holiday from $24^{\text {th }}$ to $30^{\text {th }}$ January, approximately
5 million people left Wuhan without being screened for the illness. Hundreds of millions of people travelled around the country. The spread of the virus was rapid and devastating from then on. The virus was given the official name SARS-CoV-2 and the disease was named as COVID-19 (corona virus disease-19). The WHO declared a worldwide pandemic on $11^{\text {th }}$ of March 2020. The rest is history. At the last count more than 720,000 people have been affected worldwide resulting in 33,900 deaths (as of $30^{\text {th }}$ March) especially in the older age groups and immune compromised patients. The high figures are partly due to human disregard for the rule of law and lack of civic consciousness. World over, people behaved in the most selfish manner disregarding requests and warnings, contributing to the pandemic. No one can predict what the final outcome will be. The tiny particle of SARS-CoV-2 has brought the world to a standstill and put many countries in lockdown mode.

\section{The need of a reality check}

The world and humanity today are considered to be very advanced. The emphasis is on growth, power and individuality. The buzz words are nanotechnology, robotics, genetic engineering, artificial intelligence and cyborgs. Undoubtedly these advances have made significant contributions to enhance human existence. The higher echelons of society are seeking divinity. The downside is that the human race has forgotten some fundamental moral values. Truth, honesty, civic consciousness, equity, humility, love, family values, unity and kindness are not given much thought in the fast-moving world of today. 
In the face of this tiny particle called SARS-CoV-2, aforesaid current values of power and growth seem so insignificant. The basic instinct of survival is the need of the day. This emphasizes the frailty of the humans. In many countries people died in total isolation and their main cry was for kindness and the embrace of a loved one. Even the most powerful including leaders of countries and their families were affected by the virus. Power, growth and technology did not offer any protection. Despite all the technological advances experts cautiously predict that a vaccine against COVID-19 is at least 18 months away. The new frontiers of nanotechnology, robotics, genetic engineering, artificial intelligence and cyborgs must be fully supported and advanced.

Whatever your religious beliefs are or even if you do not have one, it is time for everyone to stop and take a reality check and reexamine your life. The recent advances inebriated some people so much that they claimed that human beings could achieve immorality in the twenty first century (3).
The current epidemic calls on a reality check for such claims. This is the time to stop and think of real values in life. If humans can balance the advances and the real values that matter then the human existence will undoubtedly be enhanced and the world will become a much better place to live in. Perhaps the COVID-19 pandemic is a divine message for the world to take a reality check.

\section{References}

1. Report of the WHO-China Joint Mission on Coronavirus Disease 2019 (COVID-19).

2. Bethany Allen-Ebrahimian: https://www.axios.com/ timeline-the-early-days-of-chinas-coronavirus-outbreakand-cover-up-ee65211a-afb6-4641-97b8-353718a5faab. html

3. Alexander Bolonkin Twenty-first century - The beginning of human immortality. October 2004 Kybernetes 33(9/10): 1535-1542. DOI: 10.1108/03684920410556115. 